\title{
Information Technology Governance Practices, Challenges and Effects on Enterprise Performance*
}

\section{Bilgi Teknolojileri Yönetişim Uygulamaları, Güçlükler ve Kurumsal Performansa Etkileri}

\author{
Murat Paşa Uysal $^{1}$ (D, Evrim Çetinkaya² ${ }^{2}$ (1)
}

This submission appeared as part of Evrim Cetinkaya's master thesis, titled "The Effects of IT Governance Practices on Key Performance Indicators of Businesses" with advisor Murat Paşa Uysal

'(Prof. Dr.), Baskent University, Faculty of Commercial Sciences, Department of Management Information Systems, Ankara, Turkey

${ }^{2}$ Ufuk University, Institute of Social Sciences, Master of Business Administration Department, Ankara, Turkey

ORCID: M.P.U. 0000-0002-8349-9403 E.Ç. 0000-0003-0599-0077

Corresponding author: Murat Paşa UYSAL

Baskent University, Faculty of Commercial Sciences, Department of Management Information Systems, Ankara, Turkey E-mail address: mpuysal@baskent.edu.tr

Submitted: 27.11 .2020

Revision Requested: 16.01.2021

Last Revision Received: 19.02.202

Accepted: 23.02.2021

Published Online: 18.05.2021

Citation: Uysal, M. P., \& Cetinkaya, E. (2021) Information technology governance practices, challenges and effects on enterprise performance. Acta Infologica, 5(1), 65-78.

https://doi.org/10.26650/acin.832561

\begin{abstract}
Information Technology Governance (ITG) is important for enterprises in many respects. Acquiring better outputs from Information Technologies (IT) investments and meeting various expectations in business can be shown as primary examples. Another issue in this context is how an enterprise can manage its own IT resources according to its business strategy and functions. IT Governance Practices (ITGP), which is also described as best practices, are one of the main approaches that can be used to handle these issues. On the business side, Critical Success Factors (CSF) and Key Performance Indicators (KPI) are amongst the other tools used by enterprises for performance management. However, it is seen that there are not enough research studies exploring ITGP implementation challenges, their effects on CSF, KPI, and their relationships. In this paper, we present the findings of a qualitative research conducted according to the guidelines of Systematic Literature Review and Systematic Mapping Methods. The research outputs are promising though there are limitations that should be considered as well. Our study can be viewed as an initial attempt to the enhancement of ITGP and enterprise performance knowledge domains.
\end{abstract}

Keywords: IT Governance Practice, Enterprise Performance, Critical Success Factors, Key Performance Indicators

ÖZ

Bilgi Teknolojileri Yönetimi (BTY) birçok açıdan organizasyonlar için önemlidir. Bilişim Teknolojileri (BT) yatırımlarından daha iyi sonuç alınması ve işletmelerdeki çeşitli beklentilerin BT tarafından karşılaşması bunlara örnek gösterilebilir. Bu kapsamdaki bir diğer konu ise işletmelerin BT uygulamalarına göre kendi bilişim teknolojilerini nasıl yönetebildikleridir. En iyi uygulamalar (best practices) olarak nitelendirilen Bilgi Teknolojileri Yönetim Uygulamaları (BTYU), bu konulara çözüm getirmek üzere kullanılan yaklaşımların başında gelmektedir. Öte yandan, Kritik Başarı Faktörleri (KBF) ve Anahtar Performans Göstergeleri (APG) ise işletmeler tarafından kurumsal performans yönetiminde kullanılan araçlar arasındadır. Ancak, alan yazın taraması sonucunda BTYU'nın uygulama güçlüklerini, KBF ve APG’ne olan etkilerini ve bunlar arasındaki ilişkileri inceleyen yeterli sayıda çalışmaların bulunmadığı gözlenmiştir. Söz konusu araştırma problemine yönelik olarak bu çalışmada Sistematik Haritalama ile Sistematik Literatür Taraması yöntemlerinin bütünleştirilmesiyle gerçekleştirilen araştırmaya ait bulgular sunulmuş, sonuçlar BTYU ve kuramsal temeller çerçevesinde tartışılmıştır. Araştırmamız BTYU'nın iyileştirilmesine yönelik bir girişim olarak nitelendirilebilir.

Anahtar kelimeler: Bilgi Teknolojileri Yönetimi, Kurumsal Performans, Kritik Başarı Faktörleri, Anahtar Performans Göstergeleri 


\section{INTRODUCTION}

Enterprises have various goals and objectives, which are managed and organized with limited resources and usually dependent on internal and external factors (Khudyakova et al. 2020). The resources, such as, human, capital and materials, should be managed in an effective and efficient way in order to achieve strategic organizational goals. The ability to organize, plan, manage and control enterprise or business functions for achieving these goals is called enterprise management (Blokdyk, 2020). Marketing and sales, accounting and finance, production and manufacturing, human resources are the core business functions. In this context, Information Technologies (IT) and Information Systems (IS) have become the integral part of organizational activities, which acquire, record, transform and distribute data and information. Thus, IT and IS (ITIS) together add great value to enterprises by bringing innovative solutions to organizational problems (Rehm et al., 2015). It is possible to state that there is an increasing and strong dependency between IT and enterprises. Not only are key, core and important business processes conducted by ITIS, but also most of the daily processes are connected with digital networks, managed by digital solutions and software applications. Consequently, IT has become a change agent for transforming businesses (Ash and Burn, 2003).

Organizations usually invest in technology to develop or determine their ITIS-based strategies (Chen et al., 2011). It is hoped that managers can make better decisions, increase organizational performance as well as business profitability. ITIS has become an important instrument for realizing new products, services and business models (Arnold and Voigt, 2017). However, effective use of ITIS requires a concrete and sound understanding of organization, management and technology. Changes in strategy, organization, processes or operations may also require significant changes in IT, hardware, software and IT infrastructure (ISACA, 2020). IT has become so important for enterprises that IT Management (ITM) has already been regarded as an important business service (ITIL, 2021).

Information Technologies Management (ITM) is defined as planning and managing ITIS, collecting, processing, recording the information of businesses while transmitting them from one location to another when needed (AIS, 2020). It has a set of strategies, methods, tools and principles for the use of IT in an organization. In other words, ITM determines the authority and responsibilities in decision making processes related to ITIS. Increasing productivity, providing quality goods and services to customers, reducing costs, developing new products, assuring competitiveness of enterprises are among the important contributions provided by ITM. As a result, ITM has become one of the highest priorities for businesses and it is one of the major factors affecting the overall state of any business.

Technology investments are not only costly but also, they carry significant risks that would affect the organizational situation (Vincent et al., 2017; Okul et al., 2019). Therefore, it is of great importance to determine ITIS, not intuitively, but by following purposeful and comprehensive ITM strategies, methods and techniques. One of the concerns of managers and boards is naturally to expect a better return on investment (ROI), and therefore, they expect that ITIS will deliver what is needed to enhance the organization (NCC, 2005). As in all sectors of the industry, there are regulatory requirements and control frameworks for ITM to help enterprises manage, assess, monitor and improve their IT related processes (Barafort et al., 2017). Enterprises seek to optimize the costs by driving these standardized approaches. Moreover, they need to assess how they are performing against IT standards in view of organizational aspects (ITGI, 2020). Within this scope, it is necessary to determine, manage and control the risks arising from the use of IT. They have to provide effective and efficient information and knowledge management, which would meet business goals in an agile, continuous and secure manner (Al-Alawi et al., 2007). ITM should be based on solid foundations in order for an enterprise to manage personnel and technology efficiency, assure competitive advantage and better marketing position. Therefore, ITM has become important more than ever for improving enterprise performance.

Performance is defined as the ability or level that may be achieved by a person, group, organization or process. Performance Management (PM) provides a review of enterprise performance and contribution of business activities (Franceschini, 2007). It also verifies the achievement of strategic goals set by an organization. However, this is not an easy task. PM and control frameworks require the determination of certain areas and activities, which should also receive continuous attention from 
the management (Parmenter, 2015). Therefore, various methods, techniques and tools exist for measuring enterprise performances. Critical Success Factors (CSF) and Key Performance Indicators (KPI) are well known techniques (Trkman, 2010). CSF are the areas, which may be the conditions, characteristics or variables that can have significant impacts on the success of an organization (Samsonowa, 2012). KPI are the performance measure(s) associated with CSF, which also link the activities and day-to-day organizational performances to their corresponding CSF.

In the same sense, effective IT performance management and measurement is also an essential and integral part of the organizational success. To that aim, IT Governance (ITG) practices provide organizations with the required means to assure that the investments in IT would generate expected business value. (Haes and Grembergen, 2009). These practices' main purpose is to develop and implement organizational strategies by defining well-defined roles for the responsibility of IT processes, data, information, application and technical infrastructure (ITGI, 2020). While aligning IT with business objectives, resource management, risk management and value delivery are the other key components of ITG practices. They ensure that "IT related decisions and management are made and driven by the business and not vice versa (NCC, 2005)." Therefore, there have been various attempts to use or adopt these practices, i.e., ITIL, COBIT, CMMI. This is widespread in IT businesses; however, it often requires significant investments and has important impacts on enterprise performances. To be more concise and formally representative, the aforementioned core concepts and our research claims are described by using the formal methods as follows:

$$
\begin{aligned}
& \forall x \operatorname{CSF}\left(x_{1 . . \mathrm{n}}\right) \rightarrow \exists x \operatorname{KPI}\left(x_{1 . . \mathrm{n}}\right) \\
& \operatorname{ITG}\left(P_{1 . \mathrm{n}}\right) \rightarrow \operatorname{CSF}\left(x_{1 . . \mathrm{n}}\right) \\
& \operatorname{ITG}\left(P_{1 . \mathrm{n}}\right) \rightarrow \exists x \operatorname{KPI}\left(x_{1 . \mathrm{n}}\right)
\end{aligned}
$$

- E quation (1) indicates that for all performance measures $\mathrm{x}_{1} . . \mathrm{n}$ included in the CSF function, there exists one or more associated KPI;

- The equation (2) states that different types of ITG practices $\left(\mathrm{P}_{1} . . \mathrm{n}\right)$ should be in relation to the organizational CSF.

- Consequently, the equation (3) asserts that there should be one or more CSF-associated KPI that are also related with ITG practices.

However, it is possible to state that there is not much work that is researching the effects of ITG best practices on enterprise KPI and CSF (Haes and Grembergen, 2009). Therefore, the main purpose of this research is to explore the studies on ITG practices, implementation challenges and their effects on enterprise performances (Çetinkaya, 2017). The study is conducted by a systematic way to determine the research gaps and trends. A review protocol is developed after identifying the research questions. This protocol covers keywords to be used, databases to be scanned, search statements, paper selection criteria, methods and techniques for extracting and synthesizing data as well as research validity and reliability measures. The primary research findings are presented and they are discussed according to the theoretical background that exists in ITG and PM knowledge domains. The following sections contain the theoretical background, method, results and discussion and conclusion parts of this paper.

\section{THEORETICAL BACKGROUND}

\subsection{COBIT (Control Objectives for Information and Related Technology)}

COBIT is one of the most widely used best practices adopted as an IT management and control framework (ISACA, 2020). It plays a significant role in achieving the enterprises' goals, supporting IT and business objectives, designing IT activities using process models, determining IT resources and defining management control objectives. COBIT offers an IT management framework, a control and governance system developed by obtaining a large number of expert opinions (Figure 1). It models the IT processes that would ensure the management and control of IT resources necessary for enterprises to achieve their strategic goals. In COBIT, IT activities are conducted by IT processes that exist in four main domains. These are Align, Plan and Organize (APO), Build, Acquire and Implement (BAI), Deliver, Service and Support (DSS), Monitor, Evaluate and 
Assess (MEA). There are a total of 35 processes in these domains. APO provides a plan and organization of IT solutions and services, BAI is responsible for the realization of this plan, DSS ensures that relevant IT solutions are implemented and made available for enterprise users, and finally, MEA provides monitored and controlled IT services aligned with the plan.

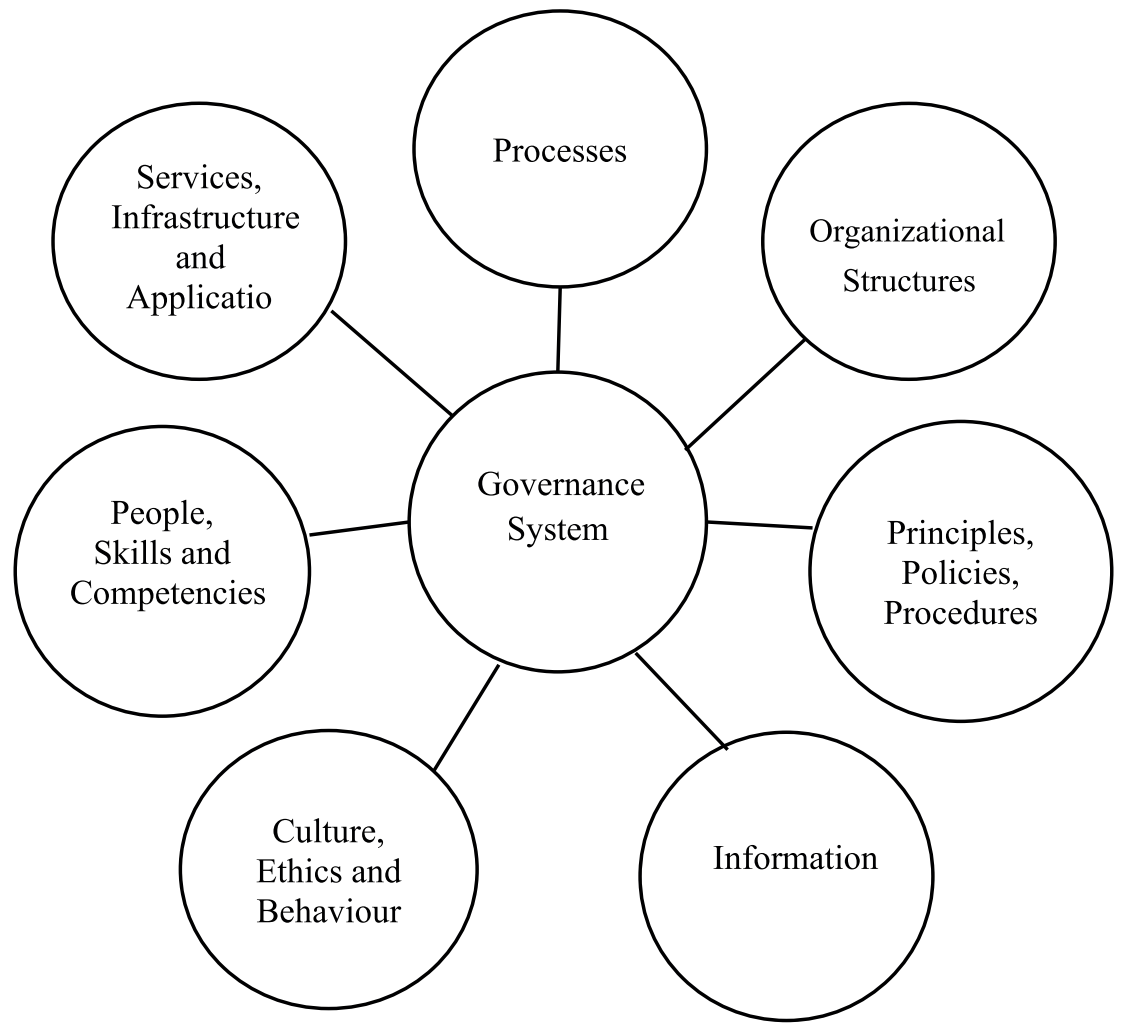

Figure 1. COBIT Components of a Governance System (ISACA, 2020)

\subsection{ITIL (Information Technology Infrastructure Library)}

ITIL is an IT service management practice, which is used to align business processes and objectives with IT management strategy that aims to provide efficient and effective IT services (ITIL, 2021). The bottom line and main purpose of IT service management in ITIL is to provide and support IT-based information services to meet business goals. It includes comprehensive descriptions of 26 processes arranged along a service lifecycle: Service Strategy (SS), Service Design (SD), Service Transition (ST), Service Operation (SO), Continual Service Improvement (CSI) respectively (Figure 2). SS determines the services that an IT organization is to offer and the capabilities needed for developing them. SD includes the design of new services as well as changes or improvements required for existing services. ST builds and deploys IT services while tries to make sure that the changes to services and their management processes are carried out in a harmonized way. SO is responsible for operational tasks and assuring that IT services are delivered efficiently and effectively. Finally, CSI improves the efficiency and effectiveness of processes and services and it uses the methods of quality management. It is known that ITIL and COBIT complement each other.

\subsection{CMMI (Capability Maturity Model Integration)}

CMMI is a process improvement framework developed by Software Engineering Institute (SEI) (CMMI, 2021). It includes three different core models; CMMI for Development (CMMI-Dev), CMMI for Acquisition (CMMI-Aqc) and CMMI for Services (CMMI-Svc). CMMI-Dev is used as a process model for management and improvement of processes in software development organizations. CMMI-Aqc is a model for organizations, which have to manage and initiate the acquisition of products or services. CMMI-Svc is, again, a process model for deploying and managing services. CMMI has two different representation models for process improvement: A staged representation and a continuous representation. The staged representation focuses on the overall organization and it provides a series of stages, which are also called as maturity levels 
indicating the maturity of an organization's set of process areas. The continuous process model, however, focuses on an individual process area and how it could be improved. It is different from the staged model in that it provides less guidance on the order of implementation and improvement of process areas. The continuous representation of CMMI uses capability levels to measure the process improvement. These levels are 0 for incomplete, 1 for performed, 2 for managed, 3 for defined, 4 for quantitatively managed and 5 for optimizing. On the other hand, the maturity levels are applied to various sets of process areas. They are represented as 1 for initial, 2 for managed, 3 for defined, 4 for quantitatively managed, 5 for optimizing respectively.

Continual Service Improvement

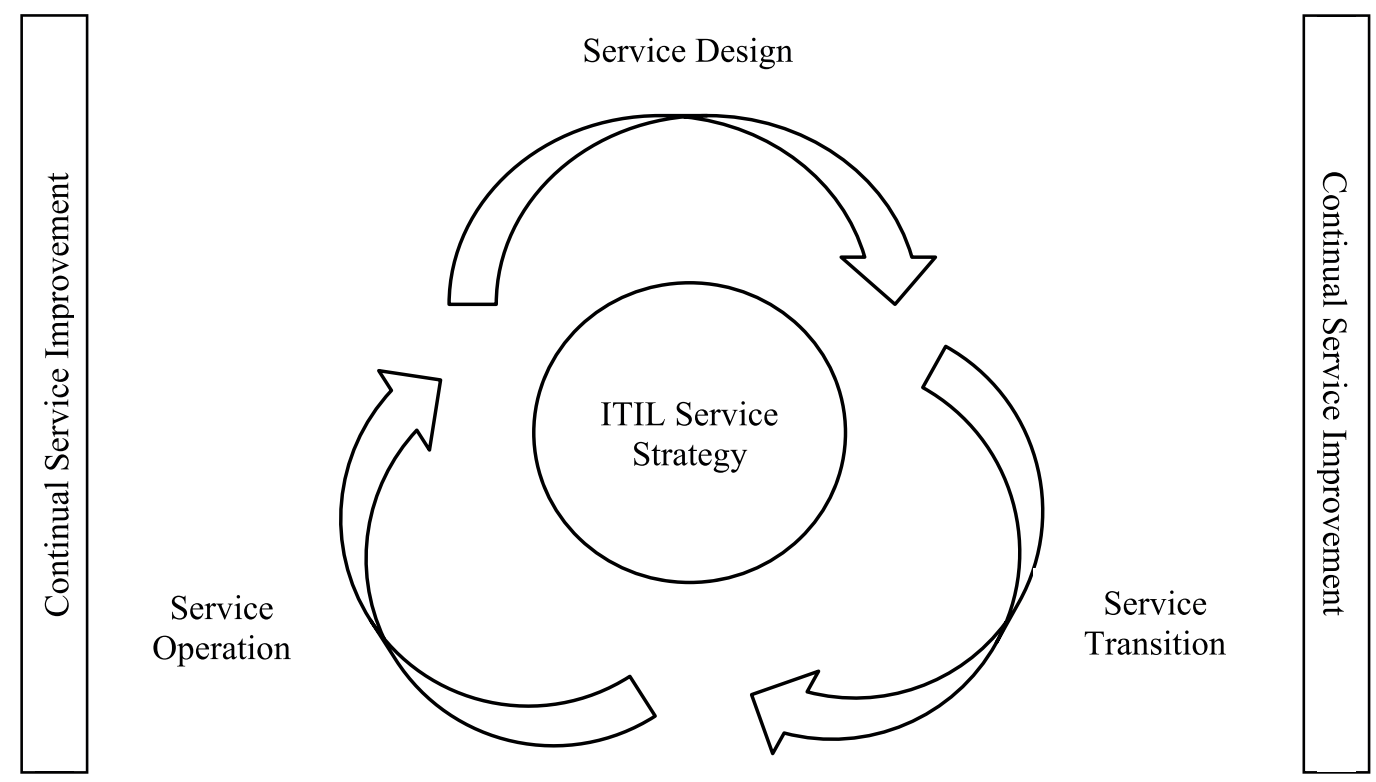

Continual Service Improvement

Figure 2. ITIL v-3 Service Lifecycle

\subsection{IT Governance}

Information Technologies Governance (ITG) is a discipline that performs IT process, risk and value chain management to ensure the effective and efficient use of IT resources in achieving strategic enterprise goals (ITGI, 2020). To this end, COBIT and ITIL are at the top of IT best practices used within the ITG knowledge domain. While COBIT sets out IT-related control objectives and performance metrics, ITIL describes what needs to be done to achieve these goals. A large part of the research related to ITG aims at the application of IT practices and standards to the organization and determining the skills and maturity levels related to IT processes (Haes and Grembergen, 2009). In some of these applications, the general situation of organizations regarding IT is determined, while in some others IT processes are explored. With the development of IT technologies, information security and risk analysis are among the popular topics. In these studies; IT management models and applications, performance, risk and security, strategic and organizational goals, IT performance measurements are examined at various enterprise levels.

\subsection{Enterprise Performance, CSF and KPI}

Today, enterprises have intensive IT or IS-dependent processes, however, the most of strategic and operational decisions are not fact-based and they are still made intuitively (Dimon, 2013). Thus, managers need performance management frameworks for analyzing, designing and implementing such systems as well as aligning ITIS with their organizational performances (Blokdyk, 2020). Therefore, CSF and KPI play an important role in this issue. CSF are the areas, which may be the conditions, characteristics or variables that can have significant impacts on the success of an organization (Samsonowa, 2012). The core 
concept is based on the notion that a limited number of factors exist, which can make a significant contribution to any enterprise's success. They are actually the few such key areas where "things must go right" for any business. Otherwise, business outcomes would be less than desired. In the IS domain, CSF are viewed as something that must happen if an ITrelated project, service, process or activity is to succeed.

KPIs focus on the aspects of performance that are the most critical for both the current and future state of organizations and they measure what has happened in terms of organizational performance. They are actually the set of performance indicators agreed on and selected upfront by management as the most representative of $r$ indicators (De Sousa, 2004). KPIs are also the measures that show how teams are performing daily and/or weekly. Thus, KPIs link the activities and day-to-day performance in the workplace to the organization's CSF that are associated with one or more KPI. While contributing to the ownership of process improvement, they provide a basis for recognizing achievements, identifying problem areas and determining organizational priorities. Parmenter (2015) suggests that KPIs may be non-financial, team-based, timely measures as well as expressing what action needs to be taken to make a difference in the current situation. Therefore, performance measures and KPIs have to be carefully developed from organizations' CSF.

\section{METHOD}

The research goal is to search, find and synthesize the studies published in the research area of ITG practices and to identify the relationships between CSF, KPI and ITG practices. Therefore, the study is conducted by integrating the Systematic Mapping (Petersen et al., 2008) and Systematic Literature Review (Kitchenham, 2004) methods and techniques. Figure 3 presents the research model.

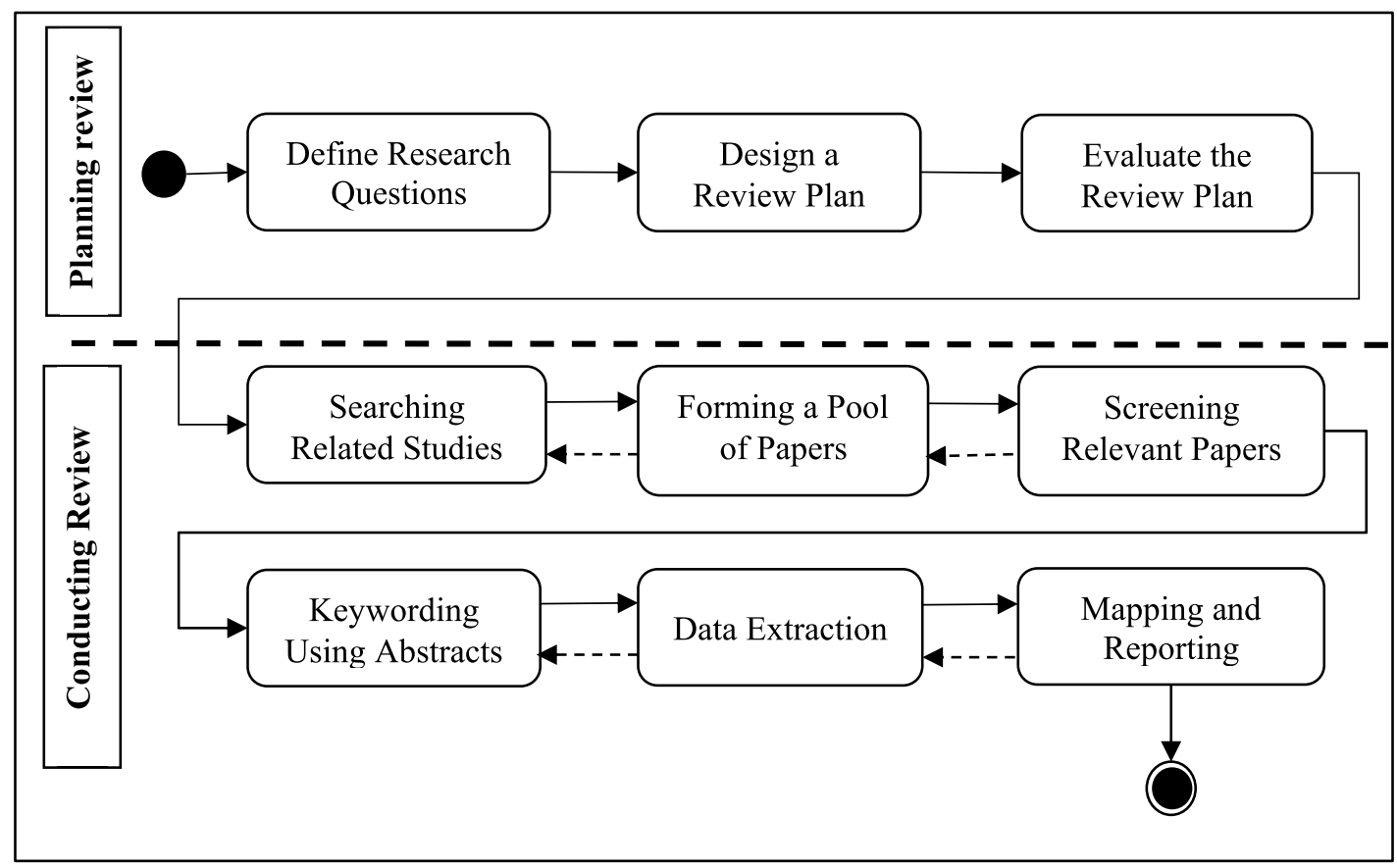

Figure 3. Research Model

\subsection{Planning Review}

The review process is a means of searching, identifying and interpreting available studies relevant to research questions. Depending on research limitations and constraints, automated search in electronic databases and the use of digital resources are determined as the main search strategy (Table 1). 
Table 1

Online databases

\begin{tabular}{lll}
\hline & Database & URL \\
\hline 1 & Science Direct & http://www.sciencedirect.com \\
2 & Taylor \& Francis & http://www.tandfonline.com \\
3 & CiteSeerX & http://citeseer.ist.psu.edu \\
4 & Google Scholar & http://scholar.google.com \\
\hline
\end{tabular}

Asking experienced researchers and experts, checking the reference lists of primary or secondary studies, accessing other web resources are determined as the ancillary search techniques. The research questions are formulated as below:

RQ-1: What are the CSF and KPI used in enterprises?

RQ-2: What are IT governance / management practices and their implementation challenges?

\subsection{Conducting Review}

The search strings and statements are developed according to the research questions along with the possible interventions, methods and factors in the context of ITG practices, CSF and KPI (Table 2):

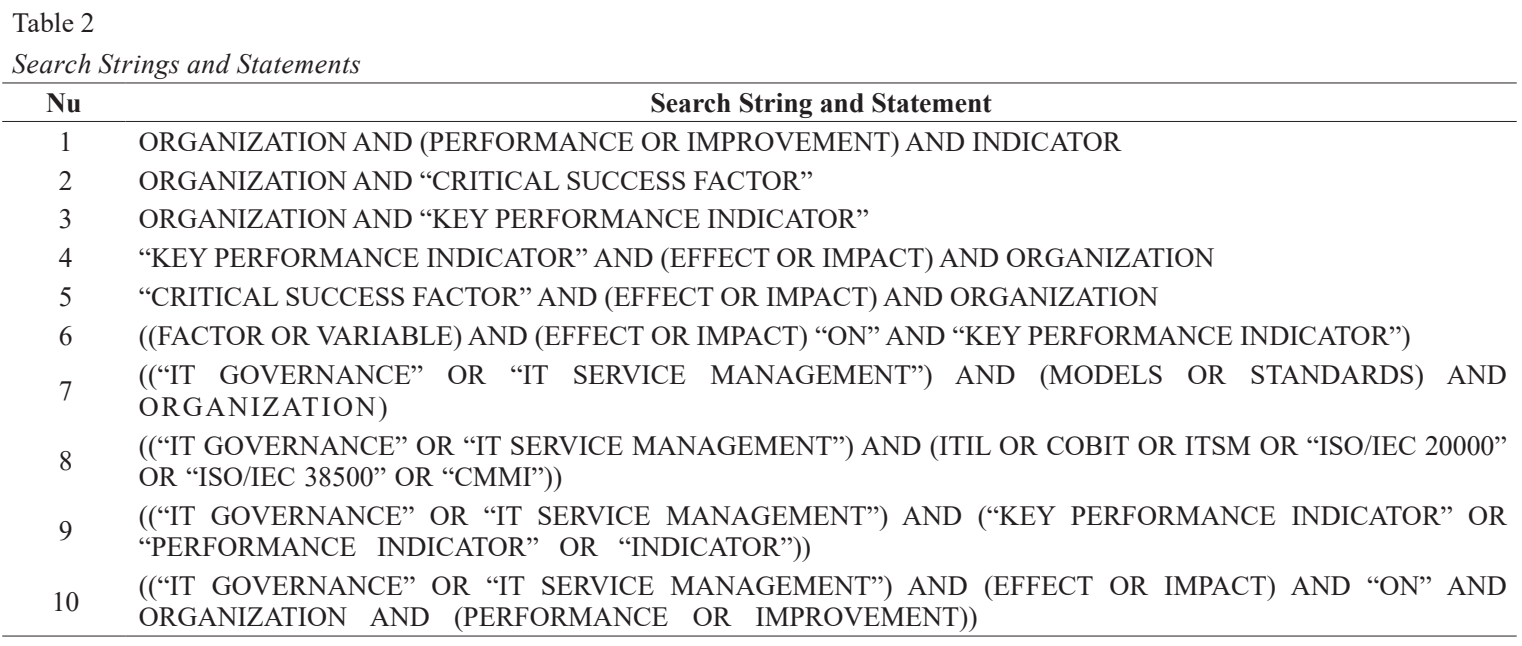

The downloaded studies formed the initial pool of papers in an online repository. It is the Google Drive Service, which is both for paper storage and information exchange between the researchers. In the next stage, the inclusion-exclusion criteria are applied for screening papers.

\subsection{Screening Relevant Papers}

The selection strategy consists of resource selection, application of the exclusion and inclusion criteria to screen relevant papers. The research questions are the main determinant of these criteria. For example, the abstracts explicitly mention ITG practices/models and KPI are directly included. The studies presenting the use of ITG for organizational improvement are also included. However, these studies are carefully reviewed in the next iterations and screened for theoretical and practical correspondence for the knowledge domain of ITG and KPI. Otherwise, they are excluded. Additionally, the papers lying outside the intersected research domain of ITG, KPI are directly excluded.

\subsection{Keywording and Data Extraction}

Data extraction and keywording is a two-step process as a way to develop a classification scheme and ensure that the existing studies were taken into account. The researchers read the abstracts and looked for similar concepts and keywords i.e. KPI, IT Governance, IT Service Management, which also reflect the context and contributions of the reviewed studies. While forming sets of keywords from the relevant papers, they were combined to establish a higher-level understanding. Then, the final sets of keywords were clustered and used to create a classification scheme for forming the categories related to KPI 
and IT Governance. Therefore, these categories were useful for interpreting and classifying without evaluating each study in detail. The data relevant to the research questions were extracted and uploaded to the online repository in addition to the descriptive information about the papers.

\section{FINDINGS AND DISCUSSION}

We were initially able to reach 460 studies using the review protocol and consequently excluded 111 papers after a screening process. The included studies were classified as 97 magazine papers, 124 journal papers, 68 conference papers, 55 research reports, 3 technical reports and 2 books. Only major observations and textual data of review study are presented here due to space constraints and research limitations. Research findings are as follows:

RQ-1: What CSF and KPI are used in enterprises?

Table 3 and Table 4 below present the number of CSF and KPI, which are classified according to business functions.

Table 3

The number of CSF classified according to business functions

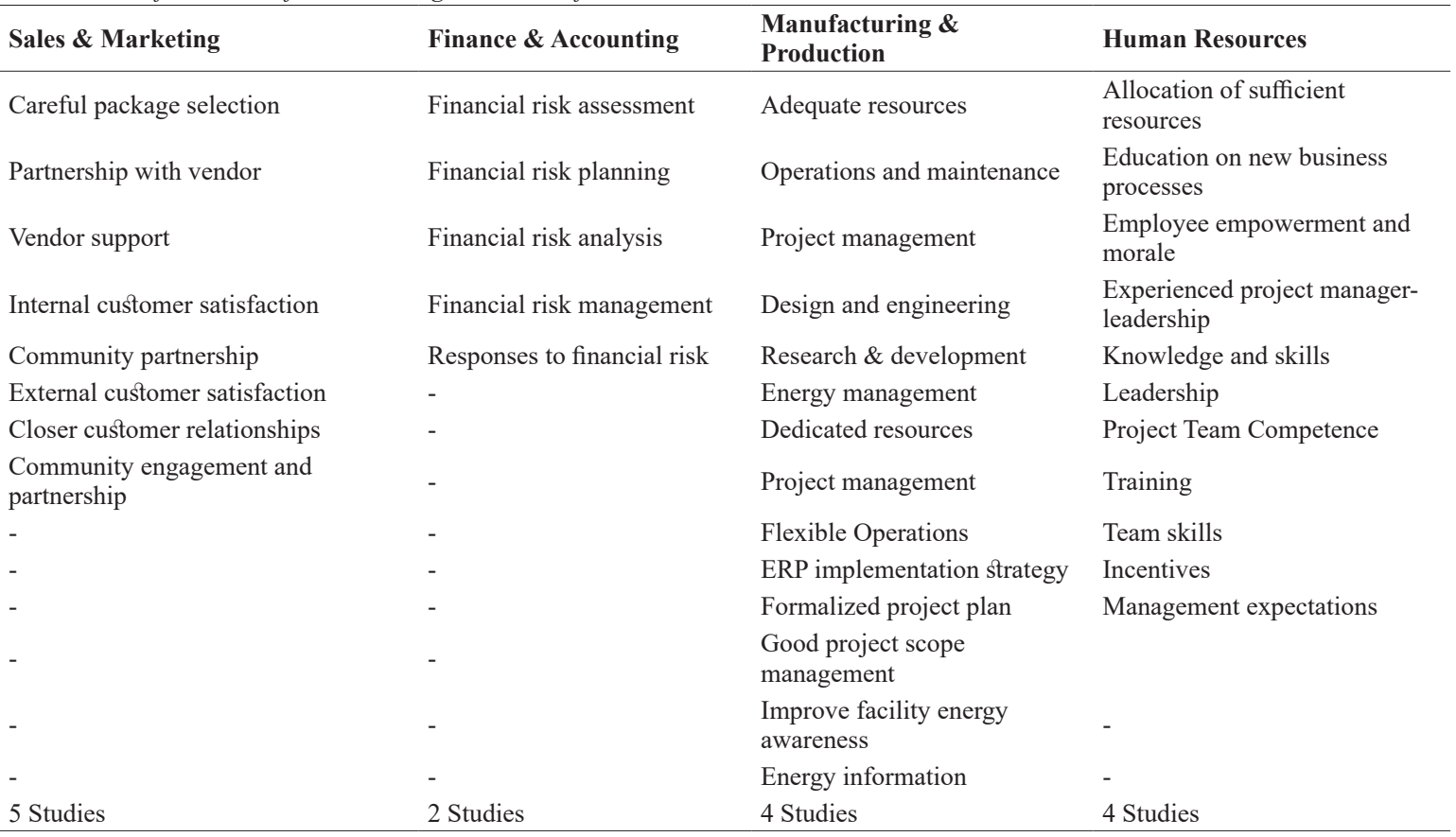

As discussed in the introduction and theoretical background sections, KPI links organizational activities and daily performances to the organizations' CSF. Performance measures and KPI also have to be developed from these organizations' CSF. Consequently, CSF should be associated with both KPI and ITG practices. However, our findings indicate that only a few studies explore and present the CSF (Table 3). On the other hand, most papers explore KPI (Table 4). This is not aligned with the research claims and is also contrary to expectations. Table 4 presents the number of KPI classified according to the business functions and sectors: 
Table 4

The number of KPI classified according to the business functions and sectors

\begin{tabular}{|c|c|c|c|c|c|}
\hline $\begin{array}{l}\text { Business Functions \& } \\
\text { Sectors }\end{array}$ & Sales \& Marketing & $\begin{array}{l}\text { Finance \& } \\
\text { Accounting }\end{array}$ & $\begin{array}{l}\text { Manufacturing \& } \\
\text { Production }\end{array}$ & Human Resources & Total \\
\hline Finance & 8 & 6 & 4 & 3 & 21 \\
\hline IT & 3 & 18 & 2 & 61 & 84 \\
\hline E-Trade & 6 & 2 & 35 & 1 & 44 \\
\hline Construction & 12 & 14 & 14 & 6 & 46 \\
\hline Health & 2 & 9 & - & 3 & 14 \\
\hline Telecom. & 22 & 1 & 5 & 1 & 29 \\
\hline Retail & 3 & 9 & 6 & - & 18 \\
\hline Production & 20 & 34 & 83 & 17 & 154 \\
\hline Others & 17 & 12 & 17 & 13 & 59 \\
\hline Total & 93 & 105 & 166 & 105 & 469 \\
\hline
\end{tabular}

In addition to these data, a set of CSF and KPI is presented in Appendix 1, which are grouped according to the business functions referenced in the reviewed papers. As can be seen from Table 4 and Appendix 1, Manufacturing \& Production and Business Function have the highest number with 166 different KPI. The numbers of Human Resources and Finance $\&$ Accounting KPI are equal. However, the Sales \& Marketing Business Function has the least amount of KPI. As for the sectors, the Production Sector is first with 154 different KPI. Then IT comes next as the second sector, in which 84 KPI are used for performance measurement. Contrary to expectations, the Finance and Health Sectors have the least amount of KPI studied, in which, in fact, the performance measurement should have a high priority when considering their mission critical roles played in our society (Dede 2016; Koyuncu, 2016).

Figure 4 below presents this knowledge in the form of a scatterplot with bubbles in order to be more powerful in giving an overview of business functions and KPI. The size of bubbles is proportional to the number of KPI that are in the pair of categories, which also corresponds to the sectors and business functions respectively.

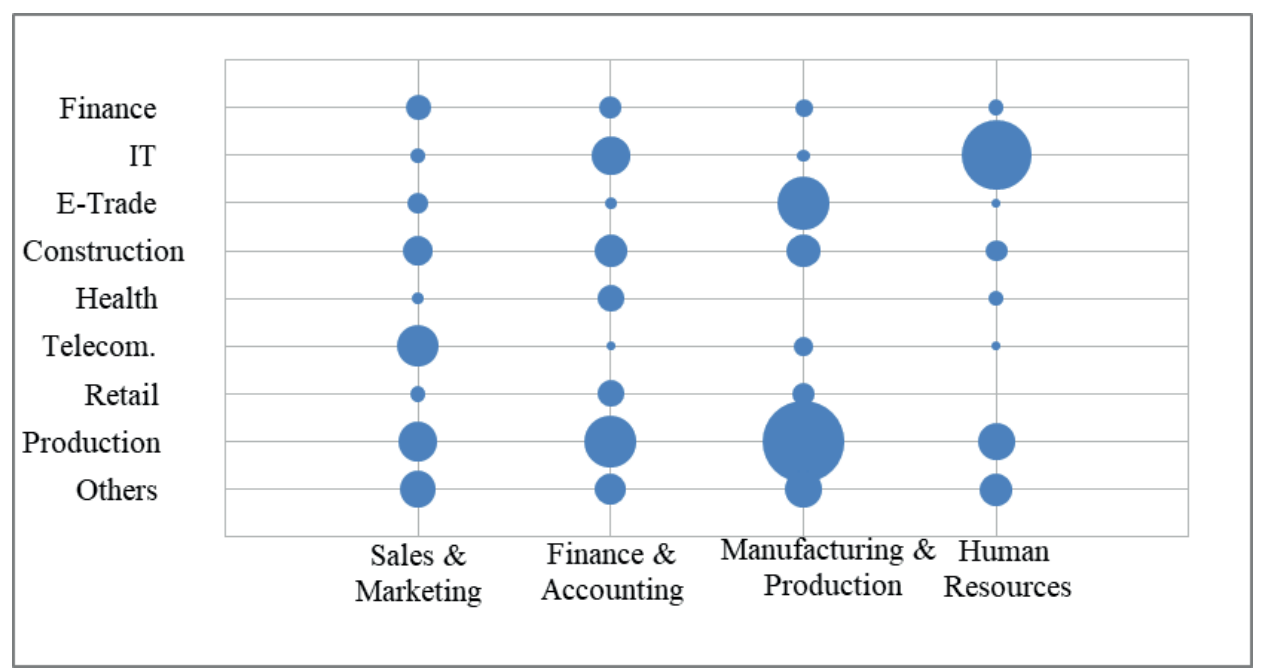

Figure 4. The Systematic Map for KPI classified according to the business functions and sectors

RQ-2: What are IT governance / management practices and their implementation challenges?

Table 5 presents each ITG practice found in the reviewed papers. As can be seen, there are 14 different practices, some of which are used not only for ITG implementations, but also for software engineering process and IT management. Although these are IT management frameworks competing for effective IT governance, ITIL, COBIT and ITSM have the highest rate of an industry-wide implementation. ITIL focuses on the IT service delivery, continuous quality improvement and it provides an IT service life cycle. COBIT, on the other hand, separates governance from management, applies a single integrated framework and adopts a holistic approach. Although they are different in nature, they have great potential for complementing each other (Uysal, 2012). 
Table 5

IT governance and/or management practices

\begin{tabular}{|c|c|c|c|}
\hline \multicolumn{4}{|c|}{ IT Governance and Management Practice } \\
\hline 1 & ITIL: Information Technology Infrastructure Library & 8 & ISO/IEC 9000: International Standard for Quality Management \\
\hline 2 & $\begin{array}{l}\text { COBIT: Control Objectives for Information and Related } \\
\text { Technologies }\end{array}$ & 9 & SIX SIGMA: Quality Management \\
\hline 3 & CMMI: Capability Maturity Model Integration & 10 & PRINCE2: Projects in Controlled Environments \\
\hline 4 & ISO/IEC 20000: IT Service Management & 11 & PMBOK: Project Management Body of Knowledge \\
\hline 5 & $\begin{array}{l}\text { ISO/IEC 38500: International Standard for Corporate } \\
\text { Governance of Information Technology }\end{array}$ & 12 & TOGAF: The Open Group Architecture Framework \\
\hline 6 & $\begin{array}{l}\text { ISO/IEC 27001: International Standard for Information } \\
\text { Security Management }\end{array}$ & 13 & MOF: Microsoft Operations Framework \\
\hline 7 & $\begin{array}{l}\text { ISO/IEC 31000: International Standard for Risk } \\
\text { Management }\end{array}$ & 14 & SQUARE: Software Quality Requirements and Evaluation \\
\hline
\end{tabular}

Table 6 below gives the ITG implementation challenges facing organizations. Lack of sufficient management support and commitment, ITG planning and its complexity and resistance to organizational change are among important challenges.

Table 6

IT governance/management practices and their implementation challenges

\begin{tabular}{|c|c|c|c|}
\hline Nu. & Implementation Challenge & IT Governance Practice(s) & $\begin{array}{l}\text { The Number of Studies } \\
\text { Referenced }\end{array}$ \\
\hline 1 & Top management resistance to change in organizational culture & ITIL, COBIT & 3 studies \\
\hline 2 & Employees' resistance to change & ITIL, CMMI & 7 studies \\
\hline 3 & Process complexity and lack of understanding & ITIL, COBIT & 8 studies \\
\hline 4 & Lack of sufficient resources for implementation & ITIL, COBIT, CMMI & 9 studies \\
\hline 5 & Lack of detailed guidelines and prescriptions & ITIL & 6 studies \\
\hline 6 & Issues on communication between different types of employees & ITIL & 3 studies \\
\hline 7 & $\begin{array}{l}\text { Unpreparedness, not being ready to plan and implement IT } \\
\text { governance practice }\end{array}$ & COBIT & 1 study \\
\hline 8 & Not allowing the skipping of the implementation steps & COBIT & 1 paper \\
\hline 9 & $\begin{array}{l}\text { Not knowing how to use or implement process metrics and } \\
\text { measures }\end{array}$ & COBIT & 1 study \\
\hline 10 & $\begin{array}{l}\text { Issues on monitoring and controlling IT governance } \\
\text { implementation processes }\end{array}$ & ITIL, COBIT & 3 studies \\
\hline 11 & Implementation issues stemming from regulatory environment & ITIL, CMMI & 3 studies \\
\hline 12 & Improper implementation & ITIL, CMMI, COBIT & 4 studies \\
\hline 13 & Issues on capability maturity levels of processes & CMMI & 1 study \\
\hline 14 & Lack of knowledge and skills & $\begin{array}{l}\text { ITIL, ISO/IEC } 38500, \text { ISO/IEC } \\
20000, \text { COBIT }\end{array}$ & 7 studies \\
\hline 15 & Unclear definition of roles and responsibilities & ITIL & 3 studies \\
\hline 16 & Lack of focus and priority during implementation & ISO/IEC 20000 & 4 studies \\
\hline 17 & Unrealistic expectations & ITIL & 2 studies \\
\hline 18 & Lack of organizational support and employees & ITIL, CMMI & 4 studies \\
\hline 19 & Unqualified personnel. & ITIL & 1 study \\
\hline 20 & Event management. & ITIL & 2 studies \\
\hline 21 & Lack of commitment & ITIL & 3 studies \\
\hline 22 & Service desk & ITIL & 1 study \\
\hline 23 & Lack of application tools and software & ITIL & 5 studies \\
\hline
\end{tabular}

IT governance is important in that organizations expect better and clear returns from IT investments to achieve strategic goals. The regulatory requirements for IT management and control as well as performance measurement against various IT standards also add much to the ITG's significance. On the business side, CSF and KPI are the frequently referenced tools for business performance management., we claim that the ITG practices should be in relation to both CSF and their associated KPI. However, the literature on ITG cannot provide sufficient evidence exploring the relationships between ITG practices, CSF and KPI.

\section{CONCLUSION}

In this paper, we present the primary findings of a systematic research study. It is conducted according to the integrated principles and guidelines of Systematic Mapping and Systematic Literature Review Methods. Our research purpose is to 
identify CSF and KPI used in organizations, ITGP and their implementation challenges. Consequently, the prominent findings and noteworthy points are as follows:

- Although KPIs have to be related to one or more CSF, this is not the case according to the research findings.

- KPIs are mostly used in the Manufacturing and Production Industry, which are also associated with the CSF for different organizations.

- There are approximately 14 types of ITGP practices and standards, together with various software engineering tools and methods, however, ITIL and COBIT practices are the foremost.

- Lack of top management support/sufficient resources, ITGP knowledge and skills, ITGP process complexity and resistance to organizational change are considered as the main implementation challenges.

- Although there are various ITGP domain-specific IT-related KPI, such as for COBIT, there is no sufficient work presenting the empirical evidence investigating the effects of ITGP on the business CSF and KPI at the time this paper was written .

The findings are encouraging though there are limitations that should be considered as well. This research can be viewed as an initial attempt to enhance ITGP, CSF and KPI knowledge and application domains. Therefore, our future research efforts will focus on the research gaps and trends put forth by this paper. It is hoped that this study may help researchers to obtain an overview of existing approaches to ITGP and enterprise performance.

Peer-review: Externally peer-reviewed.

Conflict of Interest: The authors have no conflict of interest to declare.

Grant Support: The authors declared that this study has received no financial support.

Author Contributions: Conception/Design of Study- M.P.U.; Data Acquisition- E.Ç.; Data Analysis/Interpretation- M.P.U.; Drafting Manuscript- M.P.U., E.Ç.; Critical Revision of Manuscript- M.P.U.;Final Approval and Accountability- M.P.U., E.Ç

Hakem Değerlendirmesi: Dış bağımsız.

Çıkar Çatışması: Yazar çıkar çatışması bildirmemiştir.

Finansal Destek: Yazar bu çalışma için finansal destek almadığını beyan etmiştir.

Yazar Katkıları: Çalışma Konsepti/Tasarım- M.P.U.; Veri Toplama- E.Ç.; Veri Analizi/Yorumlama- M.P.U.; Yazı Taslağı-M.P.U., E.Ç.; İçeriğin Eleştirel İncelemesi- M.P.U.; Son Onay ve Sorumluluk- M.P.U., E.Ç.

\section{Kaynaklar/References}

AIS, (2020, November 1). The Association for Information Systems. Retrieved from https://aisnet.org

Al-Alawi, A.I., Al-Marzooqi, N.Y, Mohammed, Y.F. (2007) Organizational culture and knowledge sharing: Critical success factors. Journal of Knowledge Management, 11(2), 22-42.

Arnold Christian, Voigt Kai-Ingo (2017). Ecosystem effects of the industrial internet of things on manufacturing companies. Acta Infologica, 1(2), 99-108.

Ash, C.G. \& Burn, J.M (2003). Assessing the benefits from e-business transformation through effective enterprise management. European Journal of Information Systems, 12(4), 297-308.

Barafort, B., Mesquida, A.-L. \& Mas, A. (2017). Integrating risk management in IT settings from ISO standards and management systems perspectives. Computer Standards and Interfaces, 54(1), 176-185.

Blokdyk G. (2020). Enterprise performance management a complete guide - 2020 edition. 5STARCooks, USA.

Chen, Y.-C \& Wu, J.-H (2011). IT management capability and its impact on the performance of a CIO. Information and Management, $48(5), 145-156$.

Çetinkaya, E. (2017). The effects of IT governance practices on key performance indicators in organizations. Unpublished MS Thesis, Ufuk University, Turkey.

CMMI (2021, February 6). Capability Maturity Model Integration. Software Engineering Institute, Carnegie Mellon University, USA. Retrieved from https://www.sei.cmu.edu/

de Haes, S., van Grembergen (2009). An exploratory study into IT governance implementations and its impact on business /IT alignment. Information Systems Management, 26(2), 123-137.

De Sousa, J. M. E. (2004). Definition and analysis of critical success factors for ERP implementation projects. Unpublished PhD Thesis, Universitat Politècnica de Catalunya, Barcelona, Spain.

Dede B. (2016). Building risk matrix by COSO and COBIT models in banking sector: An application for consumer loan process. Unpublished PhD Thesis, Marmara University, Turkey. 
Dimon R. (2013). Enterprise performance management done right: an operating system for your organization. Wiley, USA.

Franceschini F., Galetto M. \& Maisano, D. (2007). Management by measurement: Designing key indicators and performance measurement systems. Springer Berlin Heidelberg, USA.

ISACA (2021). Information Systems Audit and Control Association; COBIT 5: Control Objectives for Information and Related Technology Framework, ISACA, USA.

ITGI (2020). IT Governance Institute, IL, USA.

ITIL (2021, February 6). Information Technology Infrastructure Library. Retrieved from https://www.axelos.com/best-practice-solutions/itil/ what-is-itil.

Khudyakova, T., Zhuravlyov, V., Varkova, N., Aliukov, S., Shmidt, S. \& Zhuravlyov, N. (2020). Improving approaches to strategic enterprise management in the context of sustainable development. Sustainability, 12(20), 1-20.

Kitchenham, B. (2004). Procedures for performing systematic reviews. Technical Report, Keele University.

Koyuncu A. E (2016). The roles of the COBIT processes over the reliability of financial reporting and a research in banking sector. Unpublished PhD Thesis, Dumlupinar University, Turkey.

NCC Report, (2005). IT Governance: Developing a successful governance strategy. The National Computing Centre.

Okul Ş., Muratoğlu O., Aydın M.A \& Bilge H.Ş. (2019). A review on cyber risk management. Acta Infologica, 3(1), 34-45.

Parmenter D. (2015). Key performance indicators developing, implementing, and using winning KPI. John Wiley \& Sons, Inc., USA.

Petersen, K., Feldt, R., Mujtaba, S. \& Mattsso M. (2008). Systematic mapping studies in software engineering. Proceedings of the 12th International Conference on Evaluation and Assessment in Software Engineering, 68-77.

Rehm, S.-V. \& Goel, L. J. (2015). Role of information systems in empowering innovation networks. MIS Quarterly, 14(3), 87-103.

Samsonowa T. (2012). Industrial research performance management key performance indicators in the ICT industry. Springer-Verlag Berlin Heidelberg, UK.

Trkman, P. (2010). The critical success factors of business process management. International Journal of Information Management, 30(2), 125-134.

Uysal, M.P. (2012). An e-learning design model integrated with information technology governance processes. E-Journal of New World Sciences, Academy-Education Sciences, 7(1), 251-268.

Vincent, N.E., Higgs, J.L., Pinsker, R.E. (2017). IT governance and the maturity of IT risk management practices. Journal of Information Systems, 31(1), $59-77$. 


\section{Appendix-1}

\begin{tabular}{|c|c|c|c|c|c|c|c|c|}
\hline & \multicolumn{2}{|c|}{ Sales \& Marketing } & \multicolumn{2}{|c|}{ Finance \& Accounting } & \multicolumn{2}{|c|}{$\begin{array}{l}\text { Manufacturing \& } \\
\text { Production }\end{array}$} & \multicolumn{2}{|c|}{ Human Resources } \\
\hline & $\begin{array}{l}\text { Partnership with } \\
\text { vendor }\end{array}$ & Vendor support & $\begin{array}{l}\text { Financial risk } \\
\text { assessment }\end{array}$ & $\begin{array}{l}\text { Financial risk } \\
\text { management }\end{array}$ & $\begin{array}{l}\text { Adequate } \\
\text { resources }\end{array}$ & $\begin{array}{l}\text { Design \& } \\
\text { engineering }\end{array}$ & Leadership & Education \\
\hline \multirow[t]{2}{*}{ CSF } & $\begin{array}{l}\text { Internal customer } \\
\text { satisfaction }\end{array}$ & $\begin{array}{l}\text { External } \\
\text { customer } \\
\text { satisfaction }\end{array}$ & $\begin{array}{l}\text { Financial risk } \\
\text { planning }\end{array}$ & $\begin{array}{l}\text { Responses to } \\
\text { financial risk }\end{array}$ & $\begin{array}{l}\text { Operations } \\
\text { and } \\
\text { maintenance }\end{array}$ & $\begin{array}{l}\text { Research \& } \\
\text { development }\end{array}$ & Training & $\begin{array}{l}\text { Employee } \\
\text { empowerment }\end{array}$ \\
\hline & $\begin{array}{l}\text { Community } \\
\text { partnership }\end{array}$ & $\begin{array}{l}\text { Closer customer } \\
\text { relationships }\end{array}$ & $\begin{array}{l}\text { Financial risk } \\
\text { analysis }\end{array}$ & $\begin{array}{l}\text { Expected } \\
\text { commercial } \\
\text { value }\end{array}$ & $\begin{array}{l}\text { Project } \\
\text { management }\end{array}$ & $\begin{array}{l}\text { Energy } \\
\text { management }\end{array}$ & $\begin{array}{l}\text { Employee } \\
\text { satisfaction }\end{array}$ & $\begin{array}{l}\text { Knowledge and } \\
\text { skills }\end{array}$ \\
\hline \multirow{12}{*}{ KPI } & $\begin{array}{l}\text { Transaction } \\
\text { efficiency }\end{array}$ & $\begin{array}{l}\text { Number of } \\
\text { automated } \\
\text { processes }\end{array}$ & $\begin{array}{l}\text { Return on } \\
\text { investment }\end{array}$ & $\begin{array}{l}\text { Financial } \\
\text { indebtedness }\end{array}$ & $\begin{array}{l}\text { Resource } \\
\text { management }\end{array}$ & $\begin{array}{l}\text { Resource } \\
\text { utilization }\end{array}$ & $\begin{array}{l}\text { Employee } \\
\text { attendance }\end{array}$ & $\begin{array}{l}\text { Employee } \\
\text { involvement }\end{array}$ \\
\hline & $\begin{array}{l}\text { Client's objectives } \\
\text { clarified }\end{array}$ & $\begin{array}{l}\text { Profit per on-line } \\
\text { customer }\end{array}$ & $\begin{array}{l}\text { Info. Man. } \\
\text { Costs }\end{array}$ & $\begin{array}{l}\text { Supply chain } \\
\text { management } \\
\text { costs }\end{array}$ & $\begin{array}{l}\text { Failure } \\
\text { frequency }\end{array}$ & $\begin{array}{l}\text { Mean time } \\
\text { between } \\
\text { repair }\end{array}$ & $\begin{array}{l}\text { Employee } \\
\text { productivity }\end{array}$ & $\begin{array}{l}\text { Management } \\
\text { performance }\end{array}$ \\
\hline & $\begin{array}{l}\text { Customer increasing } \\
\text { rate }\end{array}$ & $\begin{array}{l}\text { Customer } \\
\text { retention rate }\end{array}$ & $\begin{array}{l}\text { Growth rate } \\
\text { of investment }\end{array}$ & $\begin{array}{l}\text { Internal rate } \\
\text { of return }\end{array}$ & $\begin{array}{l}\text { Maintenance } \\
\text { intervention }\end{array}$ & $\begin{array}{l}\text { Mean time } \\
\text { to problem } \\
\text { solution }\end{array}$ & $\begin{array}{l}\text { Employee } \\
\text { stability }\end{array}$ & $\begin{array}{l}\text { Manpower } \\
\text { Utilization rate }\end{array}$ \\
\hline & $\begin{array}{l}\text { Demand management } \\
\text { process }\end{array}$ & $\begin{array}{l}\text { Number of } \\
\text { customer referrals }\end{array}$ & $\begin{array}{l}\text { Financial } \\
\text { audit }\end{array}$ & Net income & $\begin{array}{l}\text { Quality of } \\
\text { product } \\
\text { service }\end{array}$ & $\begin{array}{l}\text { Mean down } \\
\text { time }\end{array}$ & $\begin{array}{l}\text { Team } \\
\text { performance }\end{array}$ & $\begin{array}{l}\text { Manpower } \\
\text { Efficiency }\end{array}$ \\
\hline & $\begin{array}{l}\text { Willingness to } \\
\text { purchase }\end{array}$ & $\begin{array}{l}\text { Order entry } \\
\text { accuracy }\end{array}$ & Profitability & $\begin{array}{l}\text { Net present } \\
\text { value }\end{array}$ & $\begin{array}{l}\text { Reduction in } \\
\text { tech. losses }\end{array}$ & $\begin{array}{l}\text { Equipment } \\
\text { effectiveness }\end{array}$ & Productivity & Labor efficiency \\
\hline & Increase market share & $\begin{array}{l}\text { Average waiting } \\
\text { time }\end{array}$ & Debt ratio & Capital & Efficiency & $\begin{array}{l}\text { Acceptance } \\
\text { rate }\end{array}$ & $\begin{array}{l}\text { Employees } \\
\text { trained }\end{array}$ & $\begin{array}{l}\text { Human resources } \\
\text { capital }\end{array}$ \\
\hline & Market share & Purchasing cost & Inventory cost & Revenue & $\begin{array}{l}\text { Operating } \\
\text { time }\end{array}$ & $\begin{array}{l}\text { Process } \\
\text { stability }\end{array}$ & $\begin{array}{l}\text { Investment } \\
\text { for training }\end{array}$ & Employees certified \\
\hline & Profit per customer & $\begin{array}{l}\text { Sales } \\
\text { performance }\end{array}$ & Turnover cost & Net benefit & $\begin{array}{l}\text { Process } \\
\text { improvement }\end{array}$ & $\begin{array}{l}\text { Throughput } \\
\text { rate }\end{array}$ & $\begin{array}{l}\text { Leadership } \\
\text { index }\end{array}$ & Qualification index \\
\hline & Customer visibility & $\begin{array}{l}\text { Product } \\
\text { availability }\end{array}$ & $\begin{array}{l}\text { Turnover } \\
\text { increment }\end{array}$ & $\begin{array}{l}\text { Financial } \\
\text { indebtedness }\end{array}$ & $\begin{array}{l}\text { Volume } \\
\text { flexibility }\end{array}$ & $\begin{array}{l}\text { Variance of } \\
\text { control error }\end{array}$ & $\begin{array}{l}\text { Professional } \\
\text { training }\end{array}$ & Operating hours \\
\hline & Order-to-cash & Customer lost & Liquidity & Cash flow & Availability & $\begin{array}{l}\text { Energy } \\
\text { output }\end{array}$ & $\begin{array}{l}\text { Employment } \\
\text { of labor }\end{array}$ & Labor flexibility \\
\hline & Market position & Order frequency & $\begin{array}{l}\text { Cost } \\
\text { reduction }\end{array}$ & $\begin{array}{l}\text { Financial } \\
\text { benefits }\end{array}$ & Process time & Cycle time & Turnover rate & Employee stability \\
\hline & Response time & $\begin{array}{l}\text { Customer loyalty } \\
\text { index }\end{array}$ & Total revenue & Total costs & Energy use & $\begin{array}{l}\text { Level of } \\
\text { safety }\end{array}$ & $\begin{array}{l}\text { Recruiting } \\
\text { costs }\end{array}$ & Analysis of abstain \\
\hline
\end{tabular}


